\title{
Epidermal and Fibroblast Growth Factors Behave as Mitogenic Regulators for a Single Multipotent Stem Cell-Like Population from the Subventricular Region of the Adult Mouse Forebrain
}

\author{
Angela Gritti, ${ }^{1}$ Paola Frölichsthal-Schoeller, ${ }^{1}$ Rossella Galli, ${ }^{1}$ Eugenio A. Parati, ${ }^{1}$ Lidia Cova, ${ }^{1}$ \\ Stefano F. Pagano, ${ }^{1}$ Christopher R. Bjornson, ${ }^{2}$ and Angelo L. Vescovi ${ }^{1}$ \\ ${ }^{1}$ Laboratory of Neuropharmacology, National Neurological Institute C. Besta, Milan, Italy I-20133, and 2Department of \\ Biochemistry, University of Washington, Seattle, Washington 98195-7350
}

The subventricular zone (SVZ) of the adult mammalian forebrain contains kinetically distinct precursor populations that contribute new neurons to the olfactory bulb. Because among forebrain precursors there are stem-like cells that can be cultured in the presence of mitogens such as epidermal growth factor (EGF) and fibroblast growth factor 2 (FGF2), we asked whether distinct subsets of stem-like cells coexist within the SVZ or whether the proliferation of a single type of SVZ stem-like cell is controlled by several GFs. We show that the latter is the case. Thus cells isolated from the SVZ coexpress the EGF and FGF receptors; by quantitative analysis, the number of stem-like cells isolated from the SVZ by either FGF2 or EGF is the same, whereas no additive effect occurs when these factors are used together. Furthermore, short-term administration of high-dose $\left[{ }^{3} \mathrm{H}\right]$ thymidine in vivo depletes both the EGF- and FGF2- responsive stem-like cell populations equally, showing they possess closely similar proliferation kinetics and likely belong to the constitutively proliferating SVZ compartment. By subcloning and population analysis, we demonstrate that responsiveness to more than one GF endows SVZ cells with an essential stem cell feature, the ability to vary self-renewal, that was until now undocumented in CNS stem-like cells. The multipotent stem cell-like population that expands slowly in the presence of FGF2 in culture switches to a faster growth mode when exposed to EGF alone and expands even faster when exposed to both GFs together. Analogous responses are observed when the GFs are used in the reverse order, and furthermore, these growth rate modifications are fully reversible.

Key words: EGF; FGF; stem cells; adult brain; neurogenesis; neural progenitors
The principal source of mature neural cells is the embryonic periventricular neuroepithelium (His, 1889), whose undifferentiated precursor cells give rise to neurons and glia during development (for review, see McKay, 1997). Because the germinal epithelium atrophies soon after birth and there was no evidence of postnatal neuronal generation, the idea that neurogenesis is completed early in postnatal life was widely accepted until the early 1960s (for review, see Altman and Bayer, 1993). This changed after the observation that new neurons could form postnatally in mouse cerebellar cortex (Sidman and Miale, 1959; Uzman, 1960; Miale and Sidman, 1961).

It is now clear that specific regions of primary embryonic germinal epithelium give rise to secondary and tertiary germinal matrices (Altman, 1982; Altman and Bayer, 1990a,b; Bayer and Altman, 1991) within which neurogenesis continues after birth. De novo neurogenesis has been reported in the subgranular region of the dentate gyrus, the olfactory bulb (Altman, 1962, 1969; Kaplan and Hinds, 1977; Gueneau et al., 1982; Altman and Bayer, 1990a,b; Corotto et al., 1993; Lois and Alvarez-Buylla, 1994), and the cortex (Kaplan, 1981; Huang and Lim, 1990) of

\footnotetext{
Received July 22, 1998; revised Jan. 12, 1999; accepted Feb. 10, 1999.

The research was supported by the Italian Association of Parkinsonian Patients, the Spinal Cord Society of Fergus Falls, and the Comitato Telethon (Grant A.116). We are grateful to Drs. R. D. McKay, S. Temple, A. Calof, and C. Svendsen for critically reading a previous version of this manuscript and to D. C. Ward for help with the English version of this manuscript.

Correspondence should be addressed to Dr. Angelo L. Vescovi, Laboratory of Neuropharmacology, National Neurological Institute C. Besta, Via Celoria 11, Milan, Italy I-20133.

Copyright (C) 1999 Society for Neuroscience $\quad 0270-6474 / 99 / 193287-11 \$ 05.00 / 0$
}

various adult rodent and higher mammalian species (Altman, 1966a; Das and Altman, 1971; Kaplan and Hinds, 1977; Kaplan, 1982; Rakic and Kormack, 1993).

The periventricular region and particularly the component underlying the ependymal layer of the lateral ventricles [subventricular zone (SVZ)] persist in neonate (Luskin, 1993) and adult mammals as a mitotically active layer (Allen, 1912; Kershnam, 1938; Smart, 1961) long thought to give rise to glia in the postnatal brain (Smart, 1961; Smart and Leblond, 1961; Altman, 1966b; Lewis, 1968; Patterson et al., 1973; Levison and Goldman, 1993). It is now emerging that the adult SVZ is a late germinal matrix whose molecular and cellular microenvironment is able to sustain neurogenesis via the proliferation of undifferentiated multipotent neural progenitors. In fact, the adult SVZ contains multiple precursor cell types (Doetsch et al., 1997) and at least two cell populations, as distinguished by their differing kinetic profiles [relatively quiescent and constitutively proliferating (Morshead and van der Kooy, 1994)]. In vivo, their progeny can undergo cell death (Morshead and van der Kooy, 1992) or give rise to neuronal progenitors that migrate to the olfactory bulb (Wichterle et al., 1997) to replace granule cells and periglomerular neurons (Lois and Alvarez-Buylla, 1994).

The proliferation requirements and lineage relationships of the various cell types in the SVZ of the adult mammalian forebrain remain undetermined. Previous studies showed that cells from SVZ explants proliferate and generate neurons and glia (Lois and Alvarez-Buylla, 1993), whereas stem-like cells have been isolated from the striatum of adult rodents by culturing in the presence of epidermal growth factor (EGF) (Reynolds and Weiss, 1992) or 
fibroblast growth factor 2 (FGF2) (Richards et al., 1992; Gritti et al., 1996; Johe et al., 1996). Hence, the question arises: is more than one stem-like cell type present in the adult SVZ or is there a single precursor type that responds to both EGF and FGF2, displaying stem-like features (Stemple and Mahanthappa, 1997)?

We found previously that EGF-responsive stem-like cells generate progeny that proliferates and gives rise to neurons and glia when exposed to FGF2 in vitro (Gritti et al., 1995), suggesting that FGF2-responsive cells could be the progeny of EGF-generated precursors. Here, we sought to determine the lineage relationships between EGF- and FGF2-responsive SVZ stem-like cells and to elucidate the roles of these GFs in regulating the activity of these multipotent cells of the adult mammalian forebrain.

\section{MATERIALS AND METHODS}

Primary cultures. Four- to eight-month-old CD-1 albino mice were anesthetized by intraperitoneal injection of pentobarbital $(120 \mathrm{mg} / \mathrm{kg})$ and killed by cervical dislocation. The brains were removed and placed in artificial CSF (aCSF) (124 mM NaCl, $5 \mathrm{~mm} \mathrm{KCl,} 1.3 \mathrm{~mm} \mathrm{MgCl}_{2}, 0.1 \mathrm{~mm}$ $\mathrm{CaCl}_{2}, 26 \mathrm{~mm} \mathrm{NaHCO}$, and $10 \mathrm{~mm}$ D-glucose, $\mathrm{pH} 7.3$ ) aerated with $95 \% \mathrm{O}_{2} / 5 \% \mathrm{CO}_{2}$ at room temperature. Striatal tissue, excluding subependyma, or subependyma alone was isolated after coronal sectioning and cut into $1 \mathrm{~mm}^{3}$ pieces. Pieces were transferred into $30 \mathrm{ml}$ of aCSF containing $1.3 \mathrm{mg} / \mathrm{ml}$ trypsin (Type XII, 9000 BASF units/mg; Sigma, St. Louis, MO), $0.67 \mathrm{mg} / \mathrm{ml}$ hyaluronidase (2000 units/mg; Sigma), and 0.2 $\mathrm{mg} / \mathrm{ml}$ kynurenic acid (Sigma) and incubated, under continuous oxygenation and stirring, for $90 \mathrm{~min}$ at $32-34^{\circ} \mathrm{C}$. Tissue sections were then rinsed in aCSF for $10 \mathrm{~min}$, transferred to DMEM/F12 (1:1 v/v; Life Technologies, Gaithersburg, MD) medium containing $0.7 \mathrm{mg} / \mathrm{ml}$ ovomucoid (Sigma), and carefully triturated with a fire-polished Pasteur pipette. The cells were collected by centrifugation and resuspended in GF-free, chemically defined DMEM/F12 medium containing $2 \mathrm{~mm}$ L-glutamine, $0.6 \%$ glucose, $9.6 \mathrm{gm} / \mathrm{ml}$ putrescine, $6.3 \mathrm{ng} / \mathrm{ml}$ progesterone, $5.2 \mathrm{ng} / \mathrm{ml}$ sodium selenite, $0.025 \mathrm{mg} / \mathrm{ml}$ insulin, $0.1 \mathrm{mg} / \mathrm{ml}$ transferrin, and $2 \mu \mathrm{g} / \mathrm{ml}$ heparin (sodium salt, grade II; Sigma) (control medium).

For RNA extraction and molecular analysis of GF receptors, subependymal tissue was immediately frozen in liquid nitrogen and processed as described below.

Cell culturing, propagation, cloning, and population analysis. Cells prepared as described above were plated into $35 \mathrm{~mm}$ Petri dishes (Corning, Corning, NY) containing control medium with either FGF2 (human recombinant, $20 \mathrm{ng} / \mathrm{ml}$; Peprotech, Rocky Hill, NJ, or Upstate Biotechnology, Lake Placid, NY), EGF (human recombinant, $20 \mathrm{ng} / \mathrm{ml}$; Peprotech), or both. Medium was changed every 3-4 d.

For population analyses, primary cells were plated at 3500 cells $/ \mathrm{cm}^{2}$, and the spheres formed after $8-10 \mathrm{~d}$ were harvested, collected by centrifugation $(10 \mathrm{~min}$ at $800 \times \mathrm{g})$, mechanically dissociated to a single-cell suspension, and replated in medium containing the appropriate $\mathrm{GF}(\mathrm{s})$. This procedure was repeated every 8-10 d in vitro (DIV) for up to 6 months. The total number of viable cells was assessed at each passage by trypan blue exclusion and confirmed by the calcein/propidium iodide technique.

To assess stem-like cell number in primary cultures, we established culture conditions that allowed quantitative determination of the number of stem-like cells (plated on a dish) that were responsive to EGF, FGF2, or both. The methodology was developed from our work on FGF2responsive adult neural stem cells (Gritti et al., 1996), itself borrowed from the classical assay for assessing the type and number of clonogenic cells isolated from various hemopoietic tissues (Bodine et al., 1991, 1992). Striata were dissected into parenchymal tissue that excluded the subventricular region and subventricular tissue. The tissues were dissociated to a suspension of single cells that were embedded in a methylcellulose gel matrix (1.5\% final concentration; Dow Methocell A4 M, premium grade) to prevent aggregation, plated at a final density of $<10$ viable cells $/ \mathrm{cm}^{2}$, as described previously (Gritti et al., 1996), and cultured in the presence of the appropriate GF until spherical clones were formed (8-10 DIV). Counting the number of spheres formed in the presence of FGF2, EGF, or both yielded the number of stem cells plated, which could proliferate under the conditions tested. To assess the number of single cells, doublets, and triplets in these cultures, we seeded samples onto glass coverslips and counted the cell nuclei, counterstained with 4',6- diamidino2-phenylindole dihydrochloride (DAPI; $1 \mathrm{mg} / \mathrm{ml}$ in methanol; $15 \mathrm{~min}$ at $37^{\circ} \mathrm{C}$ ).

For the tritiated thymidine ( $\left.\left[{ }^{3} \mathrm{H}\right] \mathrm{Thy}\right)$ cytotoxicity experiments, 4 - to 8-month-old CD-1 mice received three intraperitoneal injections, one every $4 \mathrm{hr}$, of $0.9 \mathrm{ml}$ of saline containing $1 \mathrm{mCi} / \mathrm{ml}\left[{ }^{3} \mathrm{H}\right] \mathrm{Thy}(64 \mathrm{Ci} / \mathrm{mmol}$; ICN Biochemicals, Costa Mesa, CA). The animals were killed $12 \mathrm{hr}$ after the last injection. Control animals received saline only. The animals were coded, and the number of stem-like cells isolated from SVZ explants devoid of striatal parenchyma was determined blind, as described in the previous paragraph and in the Results.

At every other subculturing step and after a growth factor switch, an aliquot of the cells was withdrawn from culture, and clonal spheres were generated by embedding dissociated single cells in methylcellulose and plating at a clonal density $\left(<1 \mathrm{cell} / \mathrm{cm}^{2}\right)$ in the presence of the appropriate GF. Clonal spheres were used to assay for self-renewal capacity and multipotentiality, in serial subcloning experiments. For self-renewal, individual spheres were collected by micromanipulation, dissociated to a single-cell suspension, embedded in methylcellulose, and replated as described above for primary cultures in medium containing the appropriate $\mathrm{GF}(\mathrm{s})$. The number of spheres generated under the various conditions was assessed after $8-10 \mathrm{~d}$ and normalized by the total number of cells plated into each well, as determined by direct observation $30 \mathrm{~min}$ after plating.

Retention of multipotentiality by stem cells after GF switches was assessed as described by Gritti et al. (1996). Briefly, a single-cell suspension was prepared, and individual cells were selected under high-power magnification, transferred into a single well by micromanipulation, and grown in isolation ( 1 cell/well). A mark was notched on the well to facilitate identification of the field, and microphotographs were taken at the appropriate intervals. After a clonal sphere was formed, it was further subcultured and expanded, and the progeny generated was plated onto multiple glass coverslips, differentiated, and processed for multiple immunocytochemistry, as described in the next section.

Immunocytochemistry assays. Multiple immunofluorescence assays were performed as described previously (Gritti et al., 1996). Briefly, freshly dissociated cells from subependymal tissue $\left(1000\right.$ cells $\left./ \mathrm{cm}^{2}\right)$ and serially passaged clonal spheres were plated onto polyornithine-coated glass coverslips. For differentiation experiments, cells were plated in GF-free culture medium for $5 \mathrm{~d}$, followed by the addition of fetal bovine serum for a further 2-5 DIV. Primary or differentiated cultures were fixed (20 min) with $4 \%$ paraformaldehyde in $\mathrm{PBS}, \mathrm{pH} \mathrm{7.4}$, and rinsed three times with PBS. The coverslips were then incubated for $90 \mathrm{~min}$ at $37^{\circ} \mathrm{C}$ in $\mathrm{PBS}$ containing $10 \%$ normal goat serum (NGS), $0.3 \%$ Triton $\mathrm{X}-100$, and the appropriate primary antibodies or antisera. After thorough washing with PBS and 10\% NGS, cells were reacted for 45 min (room temperature) with secondary fluorescein isothiocyanate- or rhodamine isothiocyanate-conjugated goat anti-mouse or anti-rabbit IgG antibodies (1:100; Boehringer Mannheim, Indianapolis, IN) or with donkey anti-mouse IgM antibodies coupled to 7-amino-4methylcoumarin-3-acetic acid (1:100; Jackson ImmunoResearch, West Grove, PA). The coverslips were rinsed three times in PBS and once in distilled water and mounted on glass slides with Fluorsave (Calbiochem, La Jolla, CA).

For quantitative analysis, after immunostaining, coverslips were counterstained with DAPI. The primary antibodies or antisera used were mouse monoclonal anti-microtubule-associated protein-2 (MAP2; IgG; 1:100; Boehringer Mannheim), anti-tau-microtubule-associated protein (IgG; 1:100; Boehringer Mannheim), anti- $\beta$-tubulin (IgG; 1:1250; Sig$\mathrm{ma}$ ), anti-galactocerebroside (GalC; IgG; 1:50; Boehringer Mannheim), and anti-O4 (IgM; 1:200; Boehringer Mannheim) and rabbit antisera against glial fibrillary acidic protein (GFAP; ready to use; Incstar), monoclonal anti-EGF receptor (EGFR; IgG; 1:100; Immunotech, Marseille, France), and polyclonal anti-FGF type-1 receptor (FGFR1; 1:800 gift from D. L. T. Williams). Samples were viewed and photographed with an inverted Zeiss Axiophot fluorescence microscope. No labeling was ever observed in control experiments when primary antibodies or antisera were omitted or, alternatively, when normal nonimmune serum was used. Furthermore, coverslips incubated with single primary antibodies or antisera and followed by all three secondary steps only exhibited immunoreactivity with the appropriate filter. Therefore there was no evidence of cross-reactivity.

Molecular analysis. A reverse transcription (RT)-PCR assay of mRNA was used to evaluate the expression of FGFR1 and EGFR in primary and 

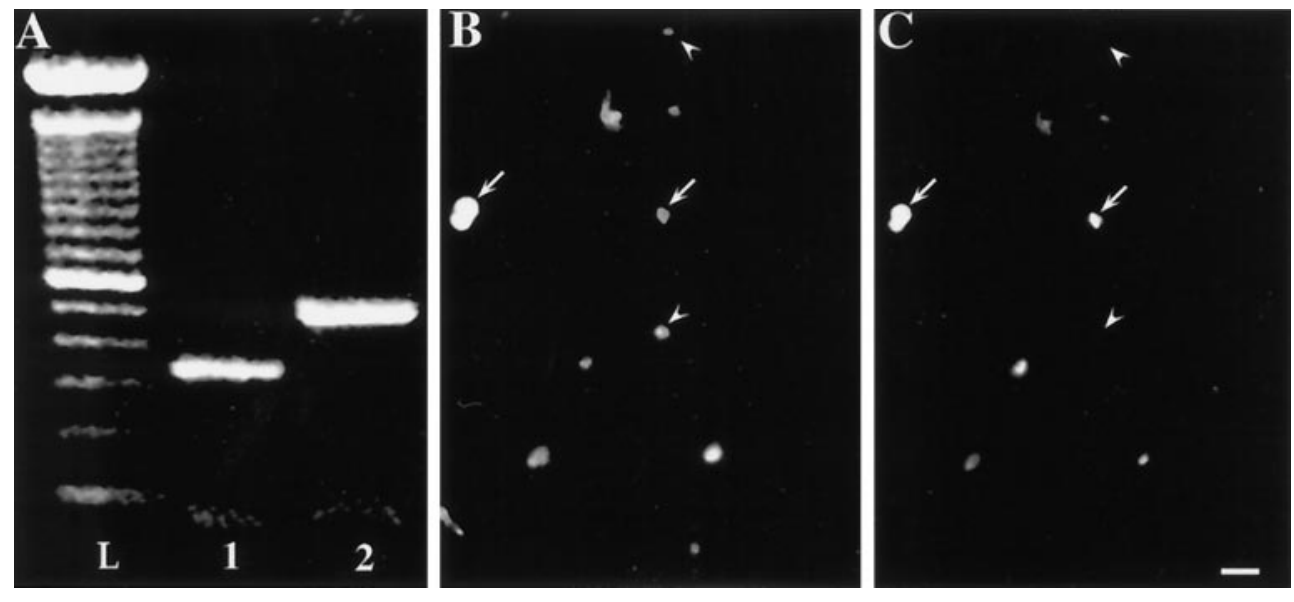

Figure 1. Cells from mouse SVZ express both EGF and FGF type-1 receptors. $A$, EGFR and FGFR1 transcripts detected in SVZ explants. Bands of the expected size are visible in the ethidium bromide-stained gel after RT-PCR on RNA extracts. L, Ladder; lane 1, EGFR, 320 bp; lane 2, FGFR1, 500 bp. $B, C$, Cells from SVZ explants processed for double immunofluorescence labeling using antibodies against the FGFR1 $(B)$ and EGFR $(C) 1 \mathrm{hr}$ after tissue dissociation. Virtually all the SVZ cells contain the FGFR1 $(B)$, whereas only a subset displays IR to both receptors $(B, C$, arrows). Although cells expressing only FGFR1 were observed $(B, C$, arrowheads), cells displaying only EGFR were never seen. Scale bar, $20 \mu \mathrm{m}$. serially passaged cell cultures. Total RNA from EGF- or FGF2-grown cell lines and from subependymal tissue was extracted using an adaptation of the method of Chomczynski and Sacchi (1987). This was reverse transcribed for $90 \mathrm{~min}$ at $42^{\circ} \mathrm{C}$, using $200 \mathrm{U}$ of Superscript RNase $\mathrm{H}$ reverse transcriptase (Life Technologies) in a $20 \mu$ l volume containing $5 \times$ first strand buffer, $0.1 \mathrm{M}$ DTT, $0.5 \mu \mathrm{g} / \mu$ l oligo-dT ${ }_{12-18}$ (Pharmacia, Uppsala, Sweden), and $10 \mathrm{~mm}$ dNTPs.

For analysis of murine FGFR1, primers corresponding to nucleotides (nt) 1143-1166 at the 5'-end of mRNA (5'-GGAAGAGAGACCAGCTGTGATGAC-3') and nt $1617-1640$ at the $3^{\prime}$-end of mRNA ( $3^{\prime}$ AACGGAGAAGG ACCTGTCGGATCT-5') were designed (size of the amplified product, $500 \mathrm{bp}$ ). For analysis of murine EGFR, nucleotide primers corresponding to nt 2058-2078 at the 5'-end of mRNA (5'GGCCTATTCATGCGAAGACG-3') and to nt 2399-2419 at the $3^{\prime}$-end of mRNA (3'-CAGGAGGCGGCATACATGAG-5') were designed (size of amplified product, $320 \mathrm{bp})$. Then $2.5 \mu \mathrm{l}$ of each $\mathrm{RT}$ reaction was amplified in a final volume of $25 \mu$ l containing $10 \times$ PCR buffer, $25 \mathrm{~mm}$ $\mathrm{MgCl}_{2}, 10 \mathrm{~mm}$ dNTPs, each primer at $50 \mu \mathrm{M}$, and $5 \mathrm{U} / \mu \mathrm{l} \mathrm{Taq}$ polymerase (Appligene Oncor, Gaithersburg, MD). PCR amplification included initial denaturation at $94^{\circ} \mathrm{C}$ for $2 \mathrm{~min}$, followed by cycles consisting of denaturation at $94^{\circ} \mathrm{C}$ for $1 \mathrm{~min}$, primer annealing at $65^{\circ} \mathrm{C}$ for $1 \mathrm{~min}$, and extension at $72^{\circ} \mathrm{C}$ for $1 \mathrm{~min}$. The PCR products were removed for analysis after 30 cycles and then separated on $1.5 \%$ agarose gels at $10 \mathrm{~V} / \mathrm{cm}$ for $2 \mathrm{hr}$; bands were visualized with ethidium bromide.

\section{RESULTS}

\section{Cells from adult SVZ express both EGF and FGF type-1 receptors}

We investigated the expression of the FGF type-1 receptor demonstrated previously in striatal embryonic stem-like cells (Vescovi et al., 1993) and the EGF receptor in cells from adult mouse SVZ. RT-PCR on mRNA isolated from SVZ explants showed the presence of both FGFR1 and EGFR transcripts (Fig. 1A). In situ immunohistochemical colocalization of GF receptors in SVZ cells is difficult, because of the scattered or fibrous distribution of antigens as shown by Morshead et al. (1994). We therefore investigated the expression of FGFR1 and EGFR at the level of individual, freshly dissociated SVZ cells using double immunofluorescence. All SVZ cells displayed anti-FGFR1-immunoreactivity (-IR) (Fig. 1B), with a subset of these cells also labeled with anti-EGFR; however, no cells labeled with anti-EGFR antibody alone (Fig. 1C). By immunohistochemistry on forebrain slices, we were able to confirm previous findings (Morshead et al., 1994) showing that the anti-EGFR-immunoreactivity is expressed in the ependymal and/or subependymal region but not in the surrounding brain parenchyma in vivo (data not shown). Thus, we conclude that virtually all the potential EGF-responsive forebrain cells that reside in the SVZ cells also express the FGFR1 receptor and, hence, may be capable of proliferating in response to both GFs.

\section{FGF2- and EGF-responsive stem-like cells colocalize within the SVZ of the adult mouse forebrain}

We sought to determine whether FGF2-responsive stem-like cells isolated from the adult striatum (Gritti et al., 1996) are located in the forebrain SVZ and to establish their lineage relationship with their EGF-responsive counterparts that also reside there (Morshead et al., 1994). To this end, primary cells were plated under clonal conditions (see below), and the number of stem-like cells in a dish was determined, retrospectively, by counting the number of spheres formed 8-10 d later in response to GFs. For this approach to be reliable, it is essential that the vast majority, if not all, of the spheres formed are derived from a single cell. To verify that this was the case, aliquots of the same cell suspensions that were plated for cell quantification were seeded onto glass coverslips, fixed soon after and up to $48 \mathrm{hr}$ later, stained with DAPI, and counted. As shown in Figure $2 A,>99 \%$ of the cells plated after tissue dissociation were single cells. Moreover, as expected from the high cell death rate typical of this type of assay, the number of doublets and triplets dramatically declined over the first 2 DIV (Fig. 2A). We also adopted measures in the assays to prevent the formation of cell doublets and triplets because of reaggregation and clustering. Because of the high rate of cell death attributable to the low cell density and lack of serum, the plating efficiency was $\sim 0.03 \%$ (see also Reynolds and Weiss, 1992). Thus, $24 \mathrm{hr}$ after plating, cell density was $\sim 10$ viable cells $/ \mathrm{cm}^{2}$ - a condition under which cell aggregation does not occur. Furthermore, embedding in methylcellulose gel prevented cell flotation and aggregation but did not hinder substrate attachment. We conclude from these investigations that virtually each sphere generated in this system was produced from a single cell. As shown previously (Reynolds and Weiss, 1992; Gritti et al., 1996), preliminary experiments confirmed that individual spheres contained cells capable of self-renewal and able to give rise to all three major neural cell lineages-neurons, astrocytes, and oligodendrocytes (data not shown) (see also Figs. 6, 7). Thus, counting the number of spheres in a well provides a reliable index of the number of stem-like cells initially plated and capable of proliferating under the conditions tested.

From these assays, we were able to show that FGF2- and EGF-generated spheres formed only in cultures obtained from SVZ-containing tissue (Fig. $2 B$ ) and that the number of spheres formed in the presence of EGF was the same as the number formed in the presence of FGF2. Both EGF- and FGF2generated primary spheres could be serially subcloned, retaining self-renewal capacity and multipotency over long-term culturing 

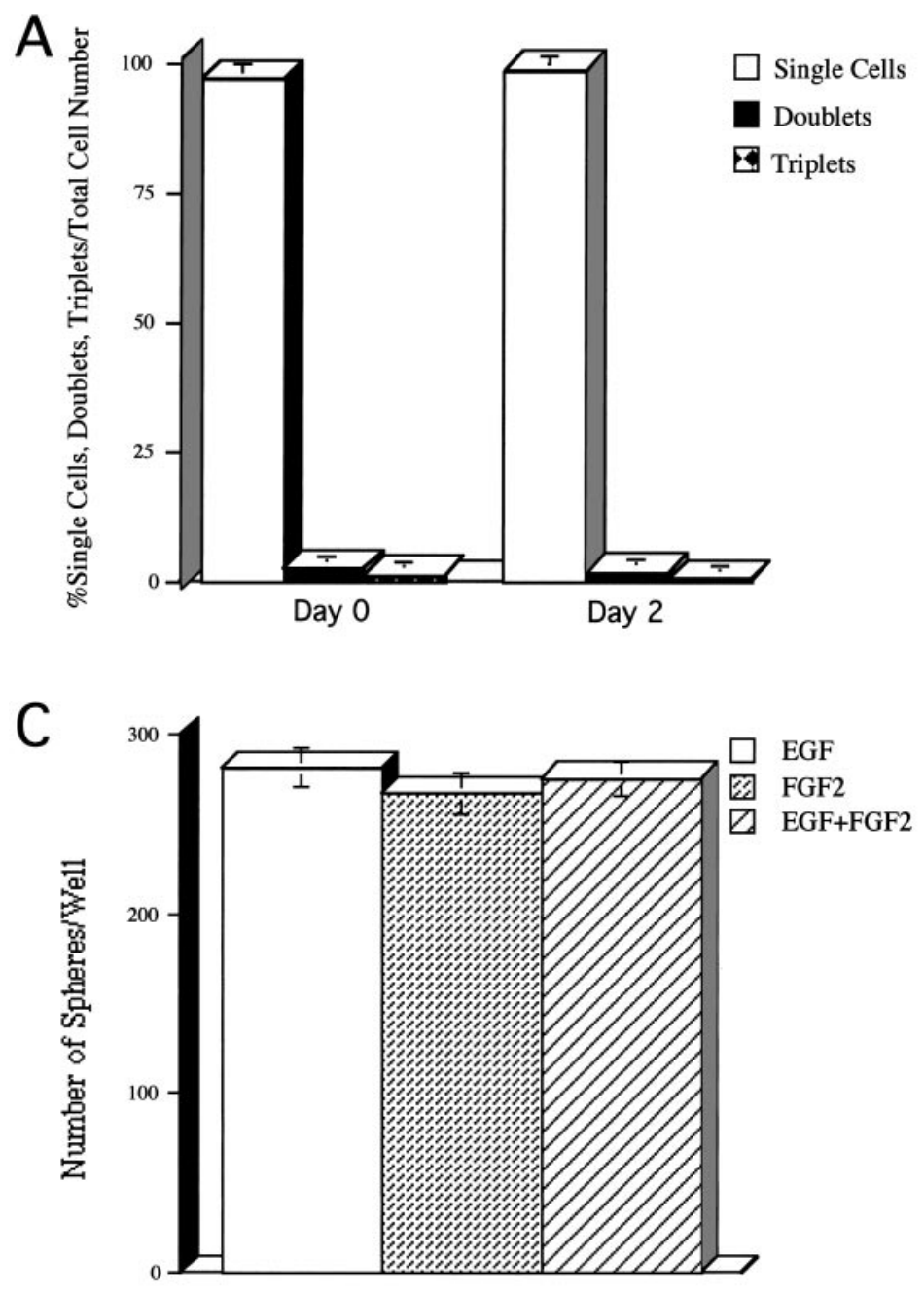
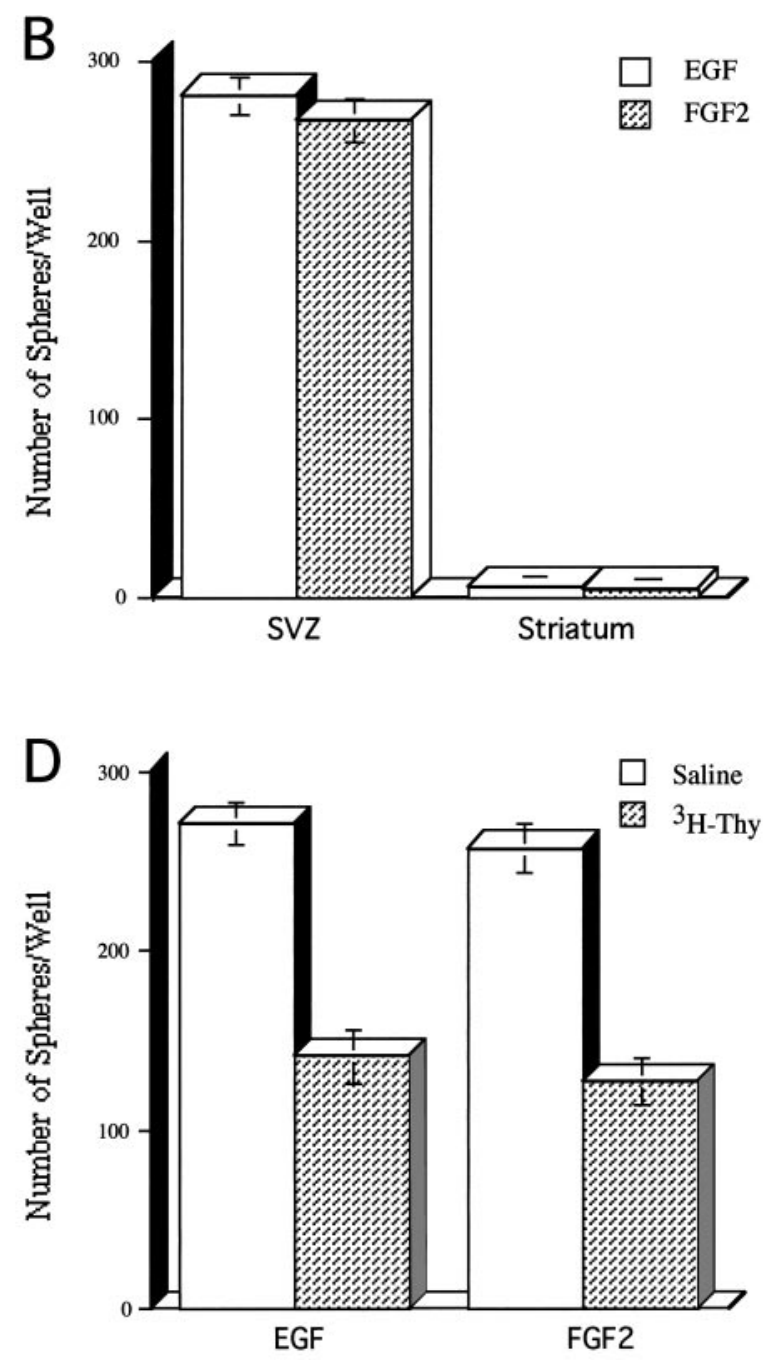

Figure 2. EGF- and FGF2-responsive CNS stem-like cells derive from the same adult SVZ precursor population that constitutively proliferates in vivo. Cells dissociated from SVZ tissue and from striatal tissue (excluding the SVZ) were plated in the presence of either EGF or FGF2 at $20 \mathrm{ng} / \mathrm{ml}$. To determine proportions of single cells, doublets, and triplets in the dissociated cells, we plated the cells onto coverslips and labeled the cells with the fluorescent nuclear-staining DAPI. $A$, The percentages of single cells, doublets, and triplets of all cells in culture are shown, determined soon after plating and $48 \mathrm{hr}$ later. These data show that the vast majority (99\%) of the cells that will eventually give rise to spheres in these cultures are single cells. $B$, Because the vast majority of spheres are formed from single cells, we were justified in using the number of spheres per well formed after $8-10$ DIV as a measure of the number of stem-like cells (see also Gritti et al., 1996). Spheres were generated exclusively from dissociated SVZ explants. Closely similar numbers of spheres were formed in response to EGF and FGF2. Data are the mean \pm SE of four independent experiments in triplicate. $C$, Freshly dissociated SVZ cells were plated in the presence of either EGF or FGF2 at $20 \mathrm{ng} / \mathrm{ml}$ or both. The cell populations that give rise to EGF- and FGF2-responsive cells are the same, because no increase in the number of clonal spheres per well was observed in the presence of both GFs compared with cultures exposed to either EGF or FGF2. Data are the mean $\pm \mathrm{SE}$ of four independent experiments in triplicate. $D$, The number of spheres per well was assessed in SVZ cultures established from animals injected with high doses of $\left[{ }^{3} \mathrm{H}\right]$ thymidine or saline (control) over $12 \mathrm{hr}$. [ $\left.{ }^{3} \mathrm{H}\right]$ thymidine caused a significant and equal decrease in the numbers of spheres generated in the presence of EGF and FGF2, showing that the SVZ precursors from which these spheres derive possess closely similar proliferation kinetics in vivo. Data are the mean \pm SE of three independent experiments in quadruplicate ( $p<0.01$ vs saline, Student's $t$ test).

(up to 21 and 18 passages for EGF- and FGF2-responsive cells, respectively; see also below). Culturing the striatal parenchyma alone (excluding the SVZ), in either an EGF- or FGF2containing medium, resulted in the production of few spheres that could not be subcultured. These observations identify the adult SVZ as the site of origin of equal quantities of EGF- and FGF2responsive stem-like cells.

\section{EGF- and FGF2-responsive stem-like cells derive from the same adult SVZ precursor population}

The above findings suggest that EGF- and FGF2-responsive stem-like cells from adult SVZ may be a single stem-like cell type.
We performed two further experiments to establish this hypothesis. First, if EGF- and FGF2-responsive stem-like cells are colocalized but distinct SVZ populations, we would expect at least a partial increase in the number of spheres formed in vitro when primary cells are cultured in the presence of FGF2 and EGF together compared with the numbers generated in response to only one GF. We found not even a slight increase in the number of spheres formed in the presence of both GFs (Fig. 2C).

Second, if EGF- and FGF2-responsive stem-like cells form a single-cell population, they should show similar in vivo proliferation kinetics. We therefore compared the numbers of EGF- and FGF2-responsive stem-like cells that could be cultured from the 

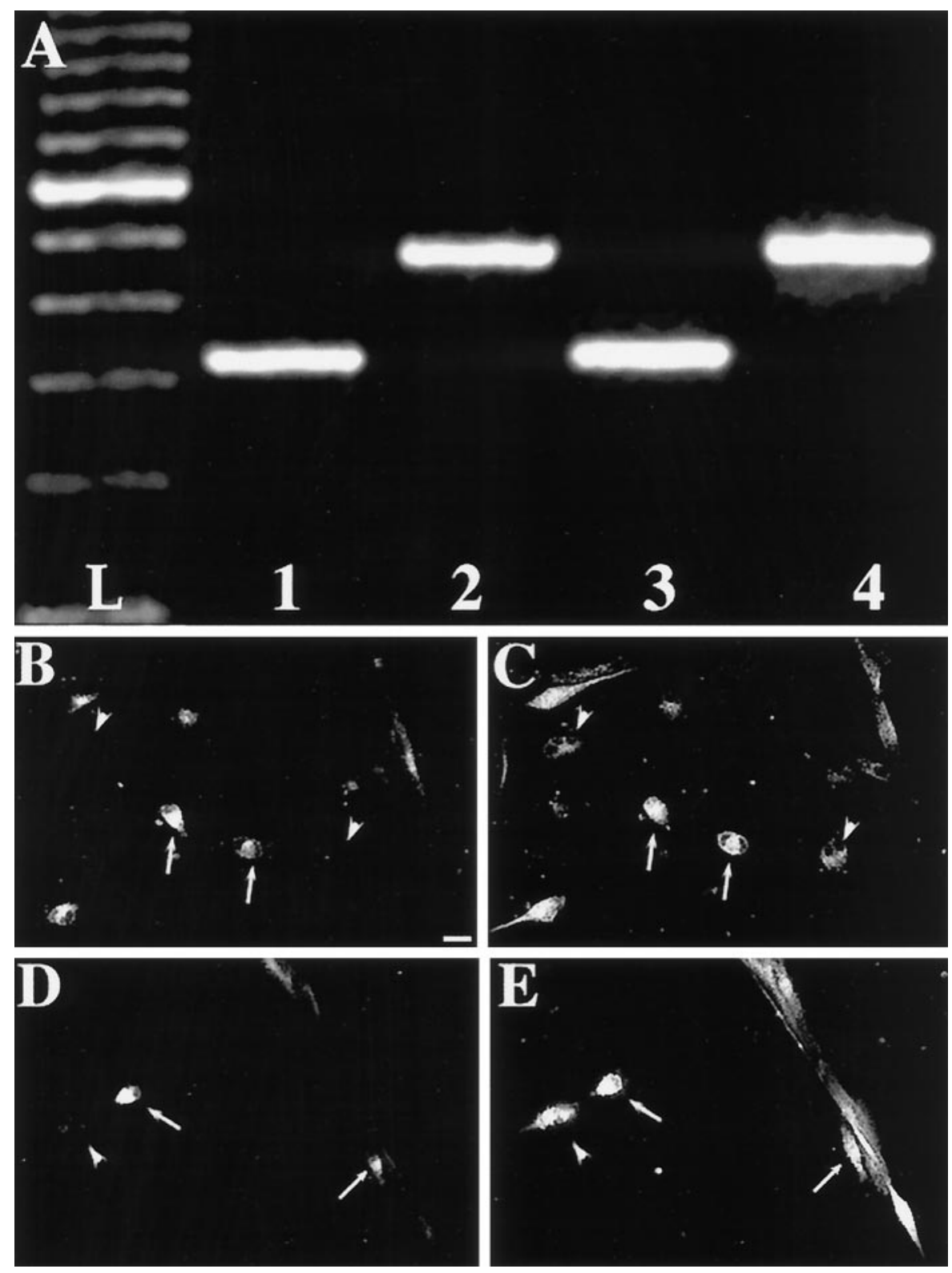

Figure 3. SVZ stem-like cells retain simultaneous expression of EGFR and FGFR1 after long-term subculturing and expansion by means of either EGF or FGF2. SVZ stem-like cell cultures serially subcultured for at least 2 months with either EGF or FGF2 contain mRNA transcripts of both EGFR and FGFR1. $A$, After RT-PCR on RNA extract from SVZ cultures grown in EGF, the transcripts of EGFR (lane 1) and FGFR1 (lane 2) are present. Both receptor transcripts are also present in cells cultured with FGF2 (lane 3, EGFR; lane 4, FGFR1). $L$, Ladder. $B-E$, Cells coexpressing EGFR $(B, D)$ and FGFR1 $(C, E)$ are detected by double immunofluorescence assay on cells serially subcultured in the presence of either EGF $(B, C$, arrows) or FGF2 (D, E, arrows). As in primary SVZ cultures, cells bearing FGFR1 but not EGFR were found in EGF- $(B, C$, arrowheads) and FGF2cultured SVZ cells ( $D, E$, arrowheads); cells displaying only EGFR-IR were never detected. Scale bar, $B-E, 25 \mu \mathrm{m}$.
SVZ of animals treated with high doses of $\left[{ }^{3} \mathrm{H}\right]$ Thy with the numbers obtained from saline-injected mice (control). Preliminary experiments based on 5-bromo-2'-deoxyuridine incorporation in vivo confirmed that, as reported previously by Morshead et al. (1994), administration of $\left[{ }^{3} \mathrm{H}\right]$ Thy produced a significant decrease $(\sim 50 \%)$ in the number of constitutively proliferating cells within the SVZ in vivo (data not shown). As shown in Figure $2 D$, the numbers of EGF- and FGF2-responsive stem-like cells isolated in vitro after $\left[{ }^{3} \mathrm{H}\right]$ Thy administration were both decreased by $50 \%$, showing that a significant fraction of both EGF- and FGF2-responsive stem-like cells possesses closely similar proliferation characteristics in vivo.

Together, these experiments show that there is a precursor cell subtype in the SVZ of the adult mouse forebrain that is able to respond to both EGF and FGF2. These EGF/FGF2-responsive cells have a cell cycle time of $12 \mathrm{hr}$ or less and are the source of the EGF- and FGF2-responsive stem-like cells isolated previously in vitro (Reynolds and Weiss, 1992; Gritti et al., 1996).

\section{EGF and FGF2 are both mitogenic regulators of the same adult SVZ stem-like cell}

Stem cells must be able to self-renew, i.e., give rise to at least one daughter identical to the mother cell at each cycle (Davis and Temple, 1994; Loeffler and Potten, 1997). Because no specific markers are available to unequivocally identify SVZ stem-like cells, their self-renewal can only be assessed by demonstrating the persistence of stem cell functional features in the progeny to which they give rise (Loeffler and Potten, 1997). In the present case we expect that EGF/FGF2-responsive SVZ stem-like cells grown by EGF stimulation will remain responsive to FGF2 after long-term subculturing and vice versa.

We tested this first by showing that EGFR and FGFR1 tran- 
scripts were present (Fig. $3 A$ ) in the progeny of SVZ stem-like cells subcultured for longer than 2 months in the presence of either EGF or FGF2. Furthermore, cells bearing both EGFR (Fig. 3B,D) and FGFR1 (Fig. 3C,E) were present in the same long-term cultures, as observed in cells freshly dissociated from SVZ explants.

Second, we performed serial clonal analysis and found that the progeny of stem-like cells subcultured for several months in the presence of EGF included cells that retained responsiveness to FGF2 and preserved both multipotentiality and the ability to self-renew. This phenomenon was also observed when the GFs were used in the reverse order. Individual EGF- or FGF2generated clonal spheres (up to passage 17; referred to as primary spheres) were dissociated and replated as single cells at clonal density, one-half in the presence of EGF and one-half in the presence of FGF2. Each EGF-generated primary sphere contained several cells with the capacity to form secondary spheres not only in the presence of EGF (EGF $\rightarrow$ EGF spheres) but also in the presence of FGF2 (EGF $\rightarrow$ FGF2 spheres), although to a significantly lesser extent $(16.21 \pm 1.46$ and $11.65 \pm 0.99 \%$ of the total number of cells plated for $\mathrm{EGF} \rightarrow \mathrm{EGF}$ and $\mathrm{EGF} \rightarrow \mathrm{FGF} 2$, respectively; $p<0.05$, Student's $t$ test). Similar results were obtained when FGF2-generated clonal spheres were dissociated and subcloned in the presence of EGF or FGF2. Even in this case, the number of secondary spheres formed in the presence of EGF (FGF2 $\rightarrow$ EGF spheres) was significantly higher than that formed in the presence of FGF2 (FGF2 $\rightarrow$ FGF2 spheres; $10.21 \pm 0.94$ and $5.01 \pm 0.77 \%$ of the total number cells plated for $\mathrm{FGF} 2 \rightarrow \mathrm{EGF}$ and FGF2 $\rightarrow \mathrm{FGF} 2$, respectively; $p<0.05$, Student's $t$ test; all data are the mean of three independent experiments; 7-13 individual primary spheres were used in each experiment). We also found that secondary spheres could be subcloned to produce EGF- and FGF-generated tertiary spheres that, when randomly sampled and differentiated, were shown to differentiate into the three major neural cell types (data not shown) (see also next paragraph).

These results indicate that EGF and FGF2 are able to substitute for each other in maintaining and expanding the SVZ stemlike cell population, although EGF seems to be more effective.

To provide further evidence of this, we extended our investigation by studying the renewal and expansion characteristics of multipotent SVZ stem-like cells in response to EGF and FGF2 at the cell population level (Loeffler and Potten, 1997). Stem-like cell cultures were established from SVZ using either EGF or FGF2 as the mitogen. After at least three passages, cultures were rinsed with control medium and dissociated, with one-half of the suspension of individual cells replated in the presence of EGF and one-half replated in the presence of FGF2 for further subculturing. This "GF switch" paradigm was sequentially repeated at least twice for both EGF- and FGF2-generated stem-like cell cultures. The number of viable cells was assessed at each subculturing step to produce cell growth curves for each switching regimen.

We found from these experiments that stem-like cells established from adult SVZ had extended self-renewal capacity; not only did they proliferate, but they consistently expanded in number when grown in FGF2-containing medium for up to 5 months (Fig. 4A). Removal of GF promptly stopped proliferation and triggered differentiation, as shown previously (Gritti et al., 1996). However, if after removal of FGF2 cells were exposed to EGF (Fig. 4A, arrow), they retained their self-renewal properties and, additionally, grew at a rate similar to that of SVZ stem-like cells always grown in only EGF (compare Fig. 4A,B). Importantly, when after a few passages in EGF these cultures were switched back to medium containing FGF2 (the GF used for initial isolation; Fig. $4 A$, arrowhead), they resumed their original, slower expansion profile (Fig. $4 A$; see doubling rates in the inset). Similarly, stem-like cells initially isolated by EGF continued to proliferate and, when plated in medium containing FGF2 (Fig. 4B, arrow), displayed the slower expansion rate typical of cells isolated by FGF2. Behavior typical of EGF-responsive stem-like cells was restored when these cells were switched back to the original medium containing EGF (Fig. 4B, arrowhead; see also inset). The peculiar behavior of both EGF- and FGF2-isolated cells after the GF switch could be reproduced consistently at any point over serial subculturing (data not shown).

Finally, we investigated the combined effect of EGF and FGF2 on the growth and/or expansion characteristics of SVZ stem-like cells. After isolation, SVZ cells were serially passaged in the presence of either EGF (Fig. $5 A$ ) or FGF2 (Fig. $5 B$ ) alone. Each culture was then dissociated and replated, one-half in medium containing the initial GF and one-half in the presence of both GFs (Fig. 5A, $B$, arrows). Irrespective of the GF used for their initial isolation, switching to medium containing both EGF and FGF2 determined a very fast expansion of the cell population, not observed previously (see also Fig. 5, insets). Once again, this phenomenon occurred irrespective of the number of previous passages in the presence of the original GF. Furthermore, the original growth characteristics were restored when the cells were switched back to medium containing the original GF (Fig. 5A, $B$, arrowhead; insets).

Over the course of these switching experiments, clonal analysis was routinely performed to show that SVZ stem-like cells retained their multipotentiality under all the conditions tested. Regardless of the number and the nature of the manipulations to which they were subjected, stem-like cells originally established either by EGF or by FGF2 always retained their ability to give rise to neurons, astrocytes, and oligodendrocytes (Figs. 6, 7). Note also that the capacity of both EGF- and FGF2-generated stem-like cells to give rise to the three neural lineages (after GF removal) was preserved after all the growth factor switches. We determined this by assessing the number of MAP2-, GFAP-, and GalC-IR cells as proportions of the total number of cells established in the presence of FGF2, switched to EGF-containing medium, switched back to FGF2, and differentiated (see also Figs. $6,7)$. We found that $13.28 \pm 0.91 \%$ neurons, $74.50 \pm 1.24 \%$ astrocytes, and $3.69 \pm 0.45 \%$ oligodendrocytes were generated. This compares with $12.07 \pm 0.84 \%$ neurons, $77.88 \pm 1.23 \%$ astrocytes, and $4.34 \pm 0.41 \%$ oligodendrocytes generated when cells established in EGF were switched to FGF2, switched back to $\mathrm{EGF}$, and differentiated (mean $\pm \mathrm{SE} ; n=6$ ).

Overall these data show that EGF and FGF2 are mitogenic effectors for a single SVZ stem-like cell population that, in turn, is able to vary reversibly its growth profile according to the GF, or GF combination, to which it is exposed.

\section{DISCUSSION}

We investigated the lineage relationships between the multipotential neural stem-like cell populations from adult mouse SVZ that are isolated and classified by their response to different GFs. We showed that both EGF- and FGF2-responsive stem-like cells derive from a single precursor cell type able to respond to both GFs. A major fraction of these precursors is constitutively proliferating within the SVZ in vivo. We also found that EGF and 

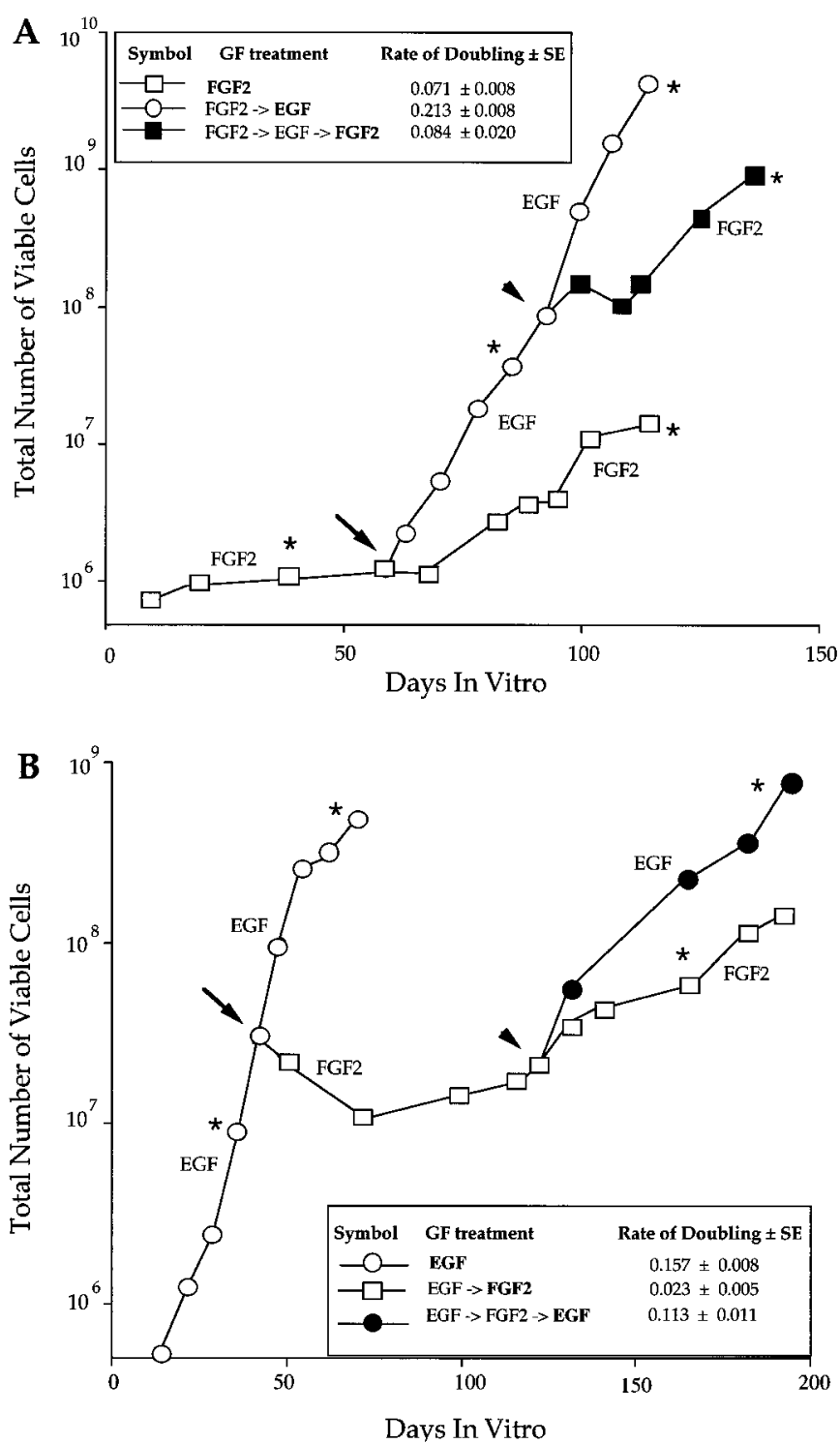

Figure 4. EGF and FGF2 are interchangeable mitogenic regulators for the same SVZ stem-like cell population in culture. Cell growth curves were obtained by assessing the total cell number after each subculturing step, under the various growth conditions analyzed. The rate of doubling (reciprocal of the doubling time; see insets) \pm SE for the growth curves was calculated after cell growth had stabilized under the new conditions (in bold in the insets) after each GF switch. The data best fitted the equation: $y=a$ - $2^{s x}$, where $y$ is the total number of cells, $x$ is the time (DIV), $s$ is the rate of doubling, and $a$ is a constant. $A$, After serial subculturing in the continuous presence of FGF2, stem-like cells were dissociated, with one-half replated (arrow) in the presence of EGF (FGF2 $\rightarrow \boldsymbol{E G F}$; open circles) and one-half replated in the presence of FGF2 (FGF2; open squares) for further serial subculturing. FGF2-responsive stem-like cells continued to proliferate and expand in number in the presence of EGF, faster than they did in response to FGF2 (see inset). After serial subculturing in EGF, stem-like cells were replated in FGF2 medium (arrowhead), in which they resumed their slow growth mode (see inset; FGF2 $\rightarrow E G F \rightarrow \boldsymbol{F G F 2}$; filled squares). $B$, Stem-like cells serially subcultured in the presence of EGF (open circles) continued to grow and expand when exposed to FGF2 (arrow; $E G F \rightarrow \boldsymbol{F G F 2}$; open squares). The cells proliferated at a slower rate in FGF2 than in EGF. However, the faster growth mode was restored when the cells were returned to EGF medium (arrowhead; EGF $\rightarrow F G F 2 \rightarrow \boldsymbol{E G F}$; filled circles; see inset). At various times, cells underwent clonal analysis to confirm the retention of multipotentiality $(A, B$, asterisks; examples shown in Figs. 6,7). The data are from one of three representative experiments yielding closely similar results.
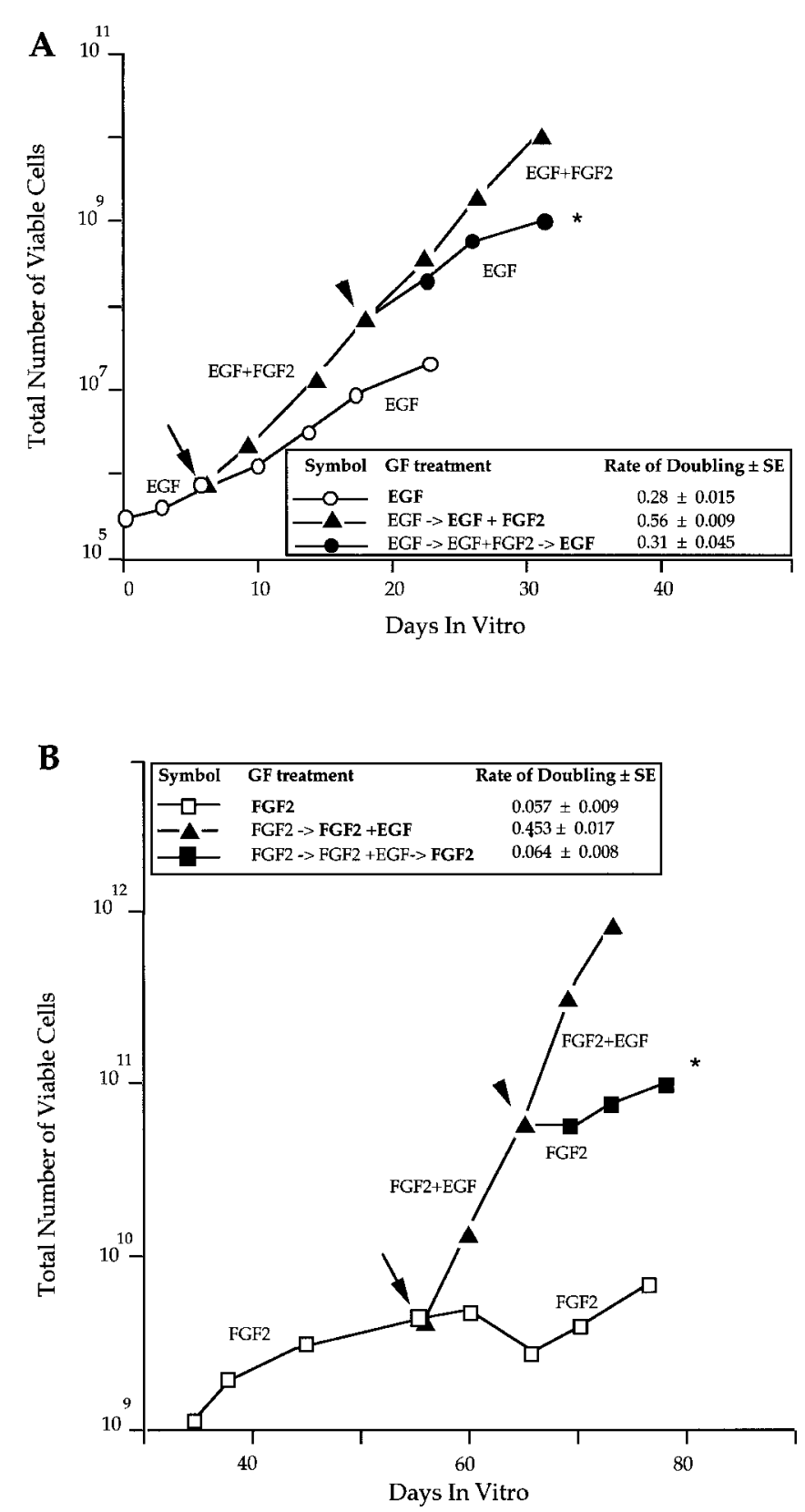

Figure 5. The expansion rate of the stem-like cell population is faster in the presence of EGF and FGF2 together than in the presence of either GF alone. Cell growth curves were obtained by assessing the total cell number after each subculturing step, under the various growth conditions. The rate of doubling (reciprocal of the doubling time; see insets) \pm SE for the growth curves was calculated after cell growth had stabilized under the new conditions (in bold in the insets) after each GF switch. The data were best fitted to the following equation: $y=a \cdot 2^{s x}$, where $y$ is the total number of cells, $x$ is the time (DIV), $s$ is the rate of doubling, and $a$ is a constant. $A$, $B$, Cells isolated and serially passaged in the presence of EGF ( $A$, open circles) or FGF2 (B, open squares) were dissociated and replated either in the presence of the initial GF or with both EGF and FGF2 $(A, B$, arrows). The expansion rate is much higher in the presence of both GFs, regardless of whether the cultures were established by EGF or FGF2 ( $E G F$ or $F G F 2 \rightarrow \boldsymbol{E G} \boldsymbol{F}+\boldsymbol{F G F}$; filled triangles). The original expansion rate was resumed when the cultures were replated in medium containing the original GF ( $A$, arrowhead; $E G F \rightarrow E G F+F G F 2 \rightarrow \boldsymbol{E G F}$; filled circles; $B$, arrowhead; $F G F 2 \rightarrow F G F 2+E G F \rightarrow \boldsymbol{F G F 2}$; filled squares; see insets for rates of doubling). At various times cells underwent clonal analysis to confirm retention of multipotentiality ( $A, B$, asterisks; examples shown in Figs. 6,7$)$. The data are from one of three experiments yielding closely similar results. 
Figure 6. SVZ stem-like cells retain multipotentiality after multiple sequential changes in culturing conditions: FGF2 $\rightarrow$ EGF $\rightarrow$ FGF2. After each GF switch, samples were taken from the culture (indicated by asterisks in Figs. 4, 5) and used to establish clonal spheres. In this case, the culture was initially established with FGF2, grown for $\sim 1$ month in EGF, then returned to FGF2, and cultured for $\sim 2$ months in this GF. Single cells were transferred to single wells (1 cell/well) by micromanipulation and followed by time-lapse microphotography. A mark was incised on the vessel to mark the field containing the cell. The progeny of a single cell was plated onto glass coverslips and allowed to differentiate for 5 DIV by removal of growth factors. The cells retained multipotentiality under all the growth conditions exemplified in Figures 4 and 5. $A, B$, The single cell shown in $A$ formed a clone by 10 DIV $(B) . C-E$, Progeny of this cell included neuronal (MAP2-IR; $C$, arrow), astroglial (GFAP-IR; $D$, arrowhead), and oligodendroglial (O4-IR; $E$ ) type cells. Scale bars: $A, B$, $25 \mu \mathrm{m} ; C-E, 10 \mu \mathrm{m}$.

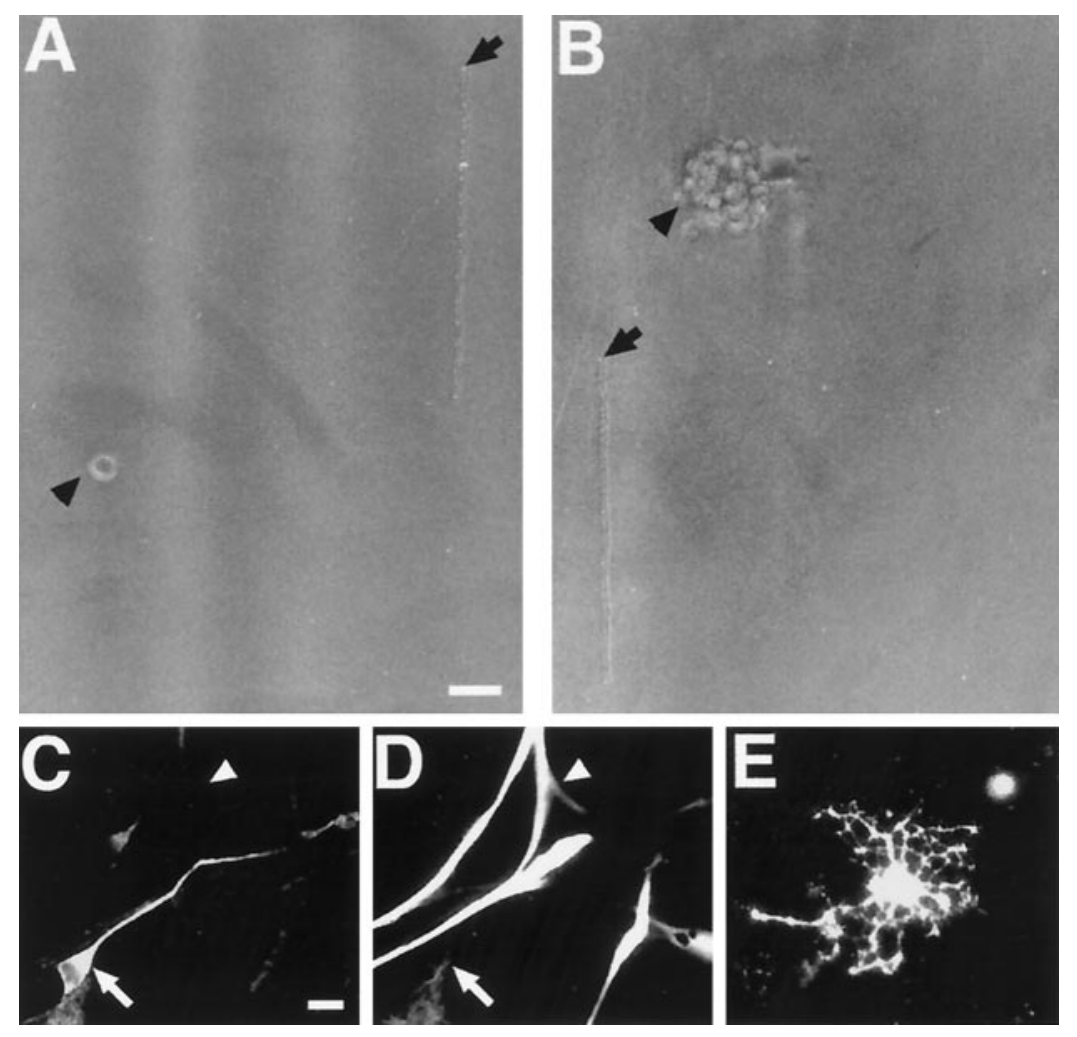

FGF2 can act interchangeably to support the self-renewal of this population and that each GF confers different growth behavior to these cells in culture. The stem cell-like population expands faster in the presence of EGF than in the presence of FGF2 and expands even faster when exposed to both GFs together. These modifications are fully reversible. Hence, we have shown that stem-like cells from the adult mammalian CNS can modulate their self-renewal characteristics and access alternative functional states in response to changes in the extracellular environment.

\section{The same, constitutively proliferating SVZ precursor type is the source of both EGF- and FGF2-responsive multipotent stem-like cells of the adult CNS}

Several lines of evidence support this conclusion. First, both EGF- and FGF2-responsive multipotent stem-like cells share a common anatomical origin, occurring exclusively in the SVZ. The very few cells from the striatal parenchyma that proliferated in response to FGF2 (Palmer et al., 1995) did not display selfrenewal potential in our hands; their limited proliferative capacity suggests they are a transiently dividing subset of FGF-responsive neural progenitors (Loeffler and Potten, 1997) that may be generated from multipotent neural stem-like cells (Vescovi et al., 1993). Alternatively, these cells may be a subset of FGF2-onlydependent forebrain precursors that may require different growth conditions to display stem cell features, as shown previously for hippocampal precursor cells (Suhonen et al., 1996).

Second, by extending work showing the presence of both EGFR and FGFR in the SVZ (Wanaka et al., 1991; Morshead et al., 1994; Gonzalez et al., 1995; Weickert and Blum, 1995), we found that the vast majority of SVZ cells bearing the EGF receptor also coexpress the FGFR1, indicating that most EGFresponsive stem-like cells can also be stimulated by FGF2.

Third, we showed that the numbers of multipotential stem-like cells that can be isolated from the SVZ by culturing with either EGF or FGF2 are experimentally identical, as expected if the two stem cell-like populations derive from the same type of precursor. More importantly, we found no increase in the number of cells isolated when the two GFs were used in combination, further indicating that the two stem-like cell populations are the same.

Finally, the SVZ contains at least two subsets of mitotically active cells, the constitutively proliferating population (with a cell cycle of $12.7 \mathrm{hr}$ ) and the relatively quiescent population [with a cell cycle of up to 28 d (Morshead and van der Kooy, 1992; Morshead et al., 1994)]. In vivo administration of high doses of $\left[{ }^{3} \mathrm{H}\right]$ Thy for $12 \mathrm{hr}$ is known to deplete severely the constitutively proliferating population, leaving the quiescent cells unchanged (Morshead et al., 1994). The equal decreases (50\%) in the numbers of stem-like cells isolated from the SVZ by either EGF or FGF2 that we observed after in vivo administration of $\left[{ }^{3} \mathrm{H}\right]$ Thy for $12 \mathrm{hr}$ show that the precursors from which these stem-like cells derive display closely similar proliferation kinetics. This finding reconciles previously incompatible properties of EGF-responsive stem-like cells. It was initially thought that these cells originate exclusively from the relatively quiescent population (Morshead et al., 1994), but it was suggested recently that they derive from the constitutively proliferating pool (Craig et al., 1996). The fact that at least one-half of the EGF-responsive elements-which we now call EGF/FGF2-responsive-have a cell cycle time of $12 \mathrm{hr}$ or less confirms that a significant fraction of these cells derives from the constitutively proliferating SVZ precursor population.

\section{The SVZ stem-like cell population can vary its self- renewal and expansion properties in a reversible manner, in response to EGF or FGF2, in vitro}

The existence of an SVZ precursor that proliferates and shows stem-like cell properties when exposed either to EGF or FGF2 

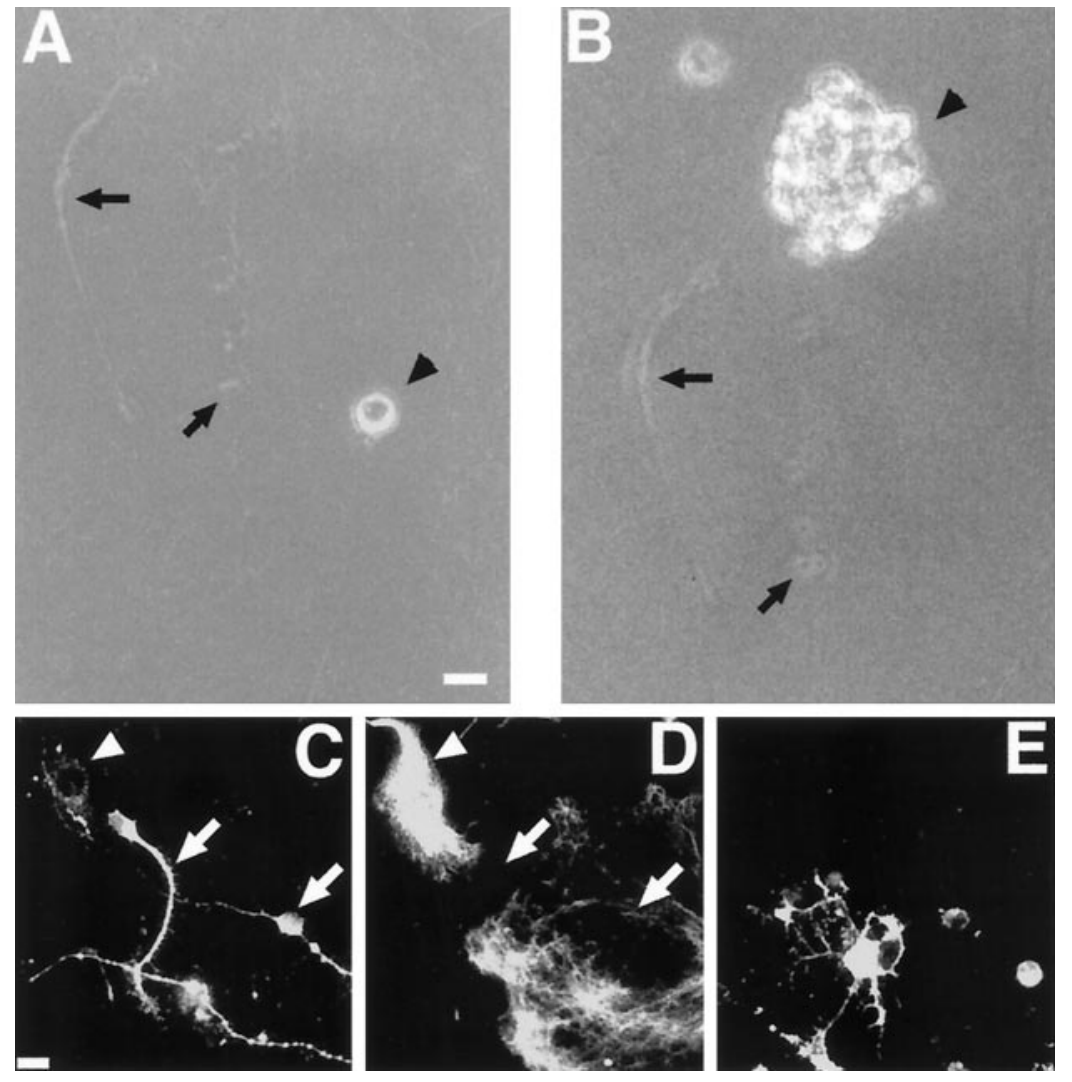

E (ivis lation and followed by time-lapse microphotography. A mark was incised on the vessel to mark the field containing the cell. The progeny of a single cell was plated onto glass coverslips and allowed to differentiate for 5 DIV by removal of growth factors. The cells retained multipotentiality under all the growth conditions exemplified in Figures 4 and 5. $A, B$, The single cell shown in $A$ formed a clone by 7 DIV $(B) . C-E$, Progeny of this cell included neuronal (MAP2-IR; $C$, arrows), astroglial (GFAP-IR; D, arrowhead), and oligodendroglial (O4-IR; $E$ ) type cells. Scale bars: $A, B, 12 \mu \mathrm{m} ; C-E, 10 \mu \mathrm{m}$. raises questions as to the functional role of this "multiple" mitogenic regulation.

A fundamental characteristic of stem cells is the ability to self-renew. At the single-cell level, this can be achieved by asymmetric division generating one stem cell and one differentiated cell or by symmetric division in which both progenies are identical to the mother cell (Loeffler and Potten, 1997). In a given population, both mechanisms may occur, along with symmetric division generating two nonstem daughter cells, and the balance between these modes determines the maintenance or expansion of the population at each generation (Loeffler and Potten, 1997). Our subcloning experiments showed that a single SVZ cell always gave rise to progeny containing more than one multipotential stem-like cell, in the presence both of EGF and of FGF2. However, a greater percentage of the progeny generated by EGF had stem-like cell characteristics, compared with those generated by FGF2. Thus, although symmetric divisions giving two stem-like cells take place in the presence of either GF, these divisions occur more frequently in the presence of EGF. Thus a substantial difference between these GFs is that EGF imposes significantly faster expansion of the SVZ stem cell-like pool than does FGF2. We cannot rule out the possibility that EGF and FGF2 may also exert differential control on cell cycle length, with SVZ stem-like cells cycling slower in the presence of FGF2; studies are presently underway to clarify this.

Our subcloning assays further showed that EGF-generated stem-like cells gave rise to progeny that was both stem cell-like and responsive to FGF2; the same phenomenon was observed when the GFs were used in the reverse order. This was expected because, having the capacity to self-renew, EGF- and FGF2responsive stem-like cells must retain responsiveness to both GFs, irrespective of which was used for the original culturing.
Furthermore, these results suggest that SVZ stem cells grown in EGF self-renew and expand at a lower rate when exposed to FGF2 alone. Similarly, cells isolated by FGF2 can still self-renew in EGF but adopt a higher rate of expansion. Confirmation of this came from cell population analysis. In fact, the proliferation kinetics of a stem cell compartment cannot be inferred only from the behavior of individual cells - as in clonal experiments-but requires analysis of a large pool of cells over an extended period (Loeffler and Potten, 1997). We investigated the growth and expansion characteristics of SVZ stem-like cells at the population level for over 6 months, showing that SVZ stem-like cells expand in response to both GFs and that, in agreement with the subcloning data, the total cell number increased significantly faster in the presence of EGF than in the presence of FGF2. Furthermore, stem-like cells initially isolated by FGF2 continued to proliferate, retained multipotentiality, and adopted a faster, EGF-like expansion kinetic profile when switched to EGF. More importantly, this change was fully reversible and independent of the time in culture. Closely similar results were obtained when the order of GF application was inverted. Furthermore, when stem-like cells cultured from either EGF or FGF2 were exposed to both GFs simultaneously, they expanded faster than in the presence of either GF alone and returned to their initial growth rate when returned to the original GF. These findings show that these adult CNS cells are endowed with an important, yet undocumented stem cell feature: the ability to vary reversibly their self-renewal characteristics (Loeffler and Potten, 1997).

Whether cells become committed to division, quiescence, or differentiation depends on a complex series of events and stimuli, involving regulation by combinations of extracellular mitogenic stimuli, including, essentially, peptide growth factors (Lukas et al., 1996). For example, multiple GFs are reported to control 
proliferation in the hemopoietic system in which various interleukins, as well as the kit ligand stem cell factor, are mitogenic for early stem-like precursor cells (Bodine et al., 1991, 1992). Similarly, the satellite stem cells of skeletal muscles possess receptors for, and undergo proliferation in response to, insulin-like GFs (Dodson et al., 1985; Allen and Boxhorn, 1989) and FGF2 (Allen et al., 1984; Allen and Boxhorn, 1989). To the best of our knowledge, however, this is the first report indicating that flexible, multifaceted epigenetic growth control may operate in stemlike cells from the adult mammalian SVZ. This is not a functional characteristic of all adult CNS stem-like cells, however, because stem-like cells from adult spinal cord are incapable of extensive proliferation in the presence of EGF or FGF alone but require simultaneous exposure to both GFs to display self-renewal (Weiss et al., 1996).

The capacity of SVZ stem-like cells to adopt different modes of proliferation and/or expansion when presented with alternative combinations of epigenetic signals may be best understood in the light of their stem cell function. Although under normal conditions the number of stem cells is stable, this can change significantly to compensate for tissue alterations (for review, see Morrison et al., 1997), implying that stem cells may react to different extracellular cues by varying their functional state. This hypothesis is consistent with previous findings indicating that (1) responsiveness to FGF2 and/or EGF may be a fundamental property of immortalized multipotent neural stem-like embryonic progenitors (Kitchens et al., 1994), (2) FGF2 may increase EGF responsiveness in embryonic striatal precursors (Ciccolini and Svendsen, 1998), and (3) FGF2 may influence the differentiation fate of cortical stem cells (Qian et al., 1997).

Thus, the differential growth regulation exerted by EGF and FGF2 on SVZ stem-like cells could be part of a basic growth regulatory module that allows neural stem cells to participate in CNS tissue homeostasis. Support for this perspective comes from the finding that a prominent function of SVZ progenitors-the contribution of new neurons to the olfactory epithelium (Lois and Alvarez-Buylla, 1994) — can be significantly altered by in vivo infusion of either of these GFs (Craig et al., 1996; Kuhn et al., 1997).

We suggest, finally, that our approach of investigating the functional properties of CNS stem-like cells at the single-cell and population level may be useful for identifying and characterizing other epigenetic effectors that regulate stem-like cell activity in the CNS. Such studies could provide additional means for manipulating or activating stem-like cells, with a view to their therapeutic use in neurodegenerative disorders, perhaps via previous ex vivo expansion, modification, and subsequent intracerebral transplantation or via in situ manipulation.

\section{REFERENCES}

Allen E (1912) Cessation of mitosis in central nervous system of the albino rat. J Comp Neurol 22:547-568.

Allen RE, Dodson MV, Luiten LS (1984) Regulation of skeletal muscle satellite cell proliferation by bovine pituitary fibroblast growth factor. Exp Cell Res 152:154-160.

Allen RE, Boxhorn LA (1989) Regulation of skeletal muscle satellite cell proliferation and differentiation by transforming growth factorbeta, insulin-like growth factor I, and fibroblast growth factor. J Cell Physiol 138:311-315.

Altman J (1962) Are new neurons formed in the brains of adult mammals? Science 135:1127-1129.

Altman J (1966a) Autoradiographic and histological studies of postnatal neurogenesis. II. A longitudinal investigation of the kinetics, migration and transformation of cells incorporating tritiated thymidine in infant rats, with special references to postnatal neurogenesis in some brain regions. J Comp Neurol 128:431-474.

Altman J (1966b) Proliferation and migration of undifferentiated precursor cells in the rat during postnatal gliogenesis. Exp Neurol 16:263-278.

Altman J (1969) Autoradiographic and histological studies of postnatal neurogenesis: cell proliferation and migration in the anterior forebrain, with special reference to persisting neurogenesis in the olfactory bulb. J Comp Neurol 137:433-458.

Altman J (1982) Morphological development of the rat cerebellum and some of its mechanism. Exp Brain Res [Suppl] 6:8-49.

Altman J, Bayer SA (1990a) Mosaic organization of the hippocampal neuroepithelium and the multiple germinal sources of dentate granule cells. J Comp Neurol 301:325-342.

Altman J, Bayer SA (1990b) Migration and distribution of two populations of hippocampal granule cell precursors during the perinatal and postnatal periods. J Comp Neurol 301:365-381.

Altman J, Bayer SA (1993) Are new neurons formed in the brains of adult mammals? In: Neuronal cell death and repair (Cuello AC, ed), pp 203-225. Amsterdam: Elsevier.

Bayer SA, Altman J (1991) Neocortical development. New York: Raven.

Bodine DM, Croisier PS, Clark SC (1991) Effects of hematopoietic growth factors on the survival of primitive stem cells in liquid suspension culture. Blood 78:914-920.

Bodine DM, Orlic D, Birkett NC, Seidel NE, Zsebo KM (1992) Stem cell factor increases colony-forming unit-spleen number in vitro in synergy with interleukin-6, and in vivo in Sl/Sld mice as a single factor. Blood 79:913-919.

Chomczynski P, Sacchi N (1987) Single-step method of RNA isolation by acid guanidinium thiocyanate-phenol-chloroform extraction. Anal Biochem 162:156-159.

Ciccolini F, Svendsen CN (1998) Fibroblast growth factor 2 (FGF-2) promotes acquisition of epidermal growth factor (EGF) responsiveness in mouse striatal precursor cells: identification of neural precursors responding to both EGF and FGF-2. J Neurosci 18:7869-7880.

Corotto FS, Henegar JA, Maruniak JA (1993) Neurogenesis persists in the subependymal layer of the adult mouse brain. Neurosci Lett 149:111-114.

Craig CG, Tropepe V, Morshead CM, Reynolds BA, Weiss S, van der Kooy D (1996) In vivo growth factor expansion of endogenous subependymal neural precursor cell populations in the adult mouse brain. J Neurosci 16:2694-2658.

Das GD, Altman J (1971) Postnatal neurogenesis in the cerebellum of the cat and tritiated thymidine autoradiography. Brain Res 30:323-330.

Davis AA, Temple S (1994) A self-renewing multipotential stem cell in embryonic rat cerebral cortex. Nature 372:263-266.

Dodson MV, Allen RE, Hossner KL (1985) Ovine somatomedin, multiplication-stimulating activity, and insulin promote skeletal muscle satellite cell proliferation in vitro. Endocrinology 117:2357-2363.

Doetsch F, Garcìa-Verdugo JM, Alvarez-Buylla A (1997) Cellular composition and three-dimensional organization of the subventricular germinal zone in the adult mammalian brain. J Neurosci 17:5046-5061.

Gonzalez AM, Berry M, Maher PA, Logan A, Baird A (1995) A comprehensive analysis of the distribution of FGF-2 and FGFR1 in the rat brain. Brain Res 701(1-2):201-226.

Gritti A, Cova L, Parati EA, Galli R, Vescovi AL (1995) Basic fibroblast growth factor supports the proliferation of epidermal growth factorgenerated neuronal precursor cells of the adult mouse CNS. Neurosci Lett 185:151-154.

Gritti A, Parati EA, Cova L, Frolichsthal P, Galli R, Wanke E, Faravelli L, Morassutti DJ, Roisen F, Nickel DD, Vescovi AL (1996) Multipotential stem-like cells from the adult mouse brain proliferate and self-renew in response to basic fibroblast growth factor. J Neurosci 16:1091-1100.

Gueneau G, Privat A, Drouet J, Court L (1982) Subgranular zone of the dentate gyrus of young rabbits as a secondary matrix. A high resolution autoradiography study. Dev Neurosci 5:345-358.

His W (1889) Die neuroblasten und deren Enstehung in embryonalen Mark. Leipzip, Germany: Hirzel.

Huang L, Lim R (1990) Identification of injury-induced mitotic cells in adult rat cerebral cortex by neuron specific markers. Dev Brain Res 51:123-127.

Johe KK, Hazel TG, Müller T, Dugich-Djordjevic MM, McKay RDG (1996) Single factors direct the differentiation of stem-like cells from foetal and adult nervous system. Genes Dev 10:3129-3140. 
Kaplan MS (1981) Neurogenesis in the 3 month-old rat visual cortex. J Comp Neurol 195:323-338.

Kaplan MS (1982) Proliferation of subependymal cells in the adult primate CNS: differential uptake of DNA labeled precursors. J Hirnforsch 23:23-33.

Kaplan MS, Hinds JW (1977) Neurogenesis in the adult rat: electron microscope analysis of light radioautographs. Science 197:1092-1094.

Kershnam J (1938) The medulloblast and the medulloblastoma. Arch Neurol Psychiatry 40:937-967.

Kitchens DL, Snyder EY, Gottlieb DI (1994) FGF and EGF are mitogens for immortalized neural progenitors. J Neurobiol 25:797-807.

Kuhn HG, Winkler J, Kempermann G, Thal LJ, Gage FH (1997) Epidermal growth factor and fibroblast growth factor-2 have different effects on neural progenitors in the adult rat brain. $\mathrm{J}$ Neurosci 17:5820-5828.

Levison SW, Goldman JE (1993) Both oligodendrocytes and astrocytes develop from progenitors in the subventricular zone of postnatal rat forebrain. Neuron 10:201-212.

Lewis PD (1968) The fate of the subependymal cell in the adult rat brain, with a note on the origin of microglia. Brain 91:721-736.

Loeffler M, Potten CS (1997) Stem-like cells and cellular pedigrees-a conceptual introduction. In: Stem-like cells (Potten CS, ed), pp 1-27. San Diego: Academic.

Lois C, Alvarez-Buylla A (1993) Proliferating subventricular zone cells in the adult mammalian forebrain can differentiate into neurons and glia. Proc Natl Acad Sci USA 90:2074-2077.

Lois C, Alvarez-Buylla A (1994) Long-distance neuronal migration in the adult mammalian brain. Science 264:1145-1148.

Lukas J, Bartkova J, Bartek J (1996) Convergence of mitogenic signalling cascades from diverse classes of receptors on the cyclin $\mathrm{D} / \mathrm{cdk}$ pRB-controlled G1 checkpoint. Mol Cell Biol 12:6917-6925.

Luskin MB (1993) Restricted proliferation and migration of postnatally generated neurons derived from the forebrain subventricular zone. Neuron 11:173-189.

McKay RDG (1997) Stem-like cells in the central nervous system. Science 276:66-71.

Miale IL, Sidman RL (1961) An autoradiographic analysis of histogenesis in the mouse cerebellum. Exp Neurol 4:277-296.

Morrison SJ, Shah NM, Anderson DJ (1997) Regulatory mechanisms in stem-like cell biology. Cell 88:287-298.

Morshead CM, van der Kooy D (1992) Postmitotic death is the fate of constitutively proliferating cells in the subependymal layer of the adult mouse brain. J Neurosci 12:249-256.

Morshead CM, Reynolds BA, Craig CG, McBurney MW, Staines WA, Morassutti D, Weiss S, van der Kooy D (1994) Neural stem-like cell in the adult mammalian forebrain: a relatively quiescent subpopulation of subependymal cells. Neuron 13:1071-1082.

Palmer TD, Ray J, Gage FH (1995) FGF-2 responsive neuronal progenitors reside in proliferative and quiescent regions of the adult rodent brain. Mol Cell Neurosci 6:474-486.
Patterson JA, Privat A, Ling EA, Leblond P (1973) Transformation of subependymal cells into glial cells as shown by radioautography after $3 \mathrm{H}$-thymidine injection into the lateral ventricle of the brain of young rats. J Comp Neurol 149:183-205.

Qian X, Davis AA, Goderie SK, Temple S (1997) FGF2 concentration regulated the generation of neurons and glia from multipotent cortical stem cells. Neuron 18:81-93.

Rakic P, Kormack DR (1993) Constraints on neurogenesis in adult primate brain: an evolutionary advantage? In: Restorative neurology, Vol 6, Neuronal cell death and repair (Cuello AC, ed), pp 257-266. Amsterdam: Elsevier.

Reynolds BA, Weiss S (1992) Generation of neurons and astrocytes from isolated cells of the adult mammalian central nervous system. Science 255:1707-1710.

Richards LJ, Kilpatrick TJ, Bartlett PF (1992) De novo generation of neuronal cells from the adult mouse brain. Proc Natl Acad Sci USA 89:8591-8595.

Sidman HL, Miale IL (1959) Histogenesis in the mouse cerebellum studied by autoradiography with tritiated thymidine. Anat Rec 133:429-430.

Smart I (1961) The subependymal layer of the mouse brain and its cell production as shown by radioautography after $3 \mathrm{H}$-thymidine injection. J Comp Neurol 116:325-338.

Smart I, Leblond CP (1961) Evidence for division and transformation of neuroglia cells in the mouse brain as derived from radioautography after injection with 3H-thymidine. J Comp Neurol 116:359-366.

Stemple DL, Mahanthappa NK (1997) Neural stem cells are blasting off. Neuron 18:1-4.

Suhonen JO, Peterson DA, Ray J, Gage FH (1996) Differentiation of adult hippocampus-derived progenitors into olfactory neurons in vivo. Nature 383:624-627.

Uzman L (1960) The histogenesis of the mouse cerebellum as studied by its tritiated thymidine uptake. J Comp Neurol 114:137-145.

Vescovi AL, Reynolds BA, Fraser DD, Weiss S (1993) bFGF regulates the proliferative fate of unipotent (neuronal) and bipotent (neuronal/ astroglial) EGF-generated CNS progenitor cells. Neuron 11:951-966.

Wanaka A, Milbrandt J, Johnson Jr EM (1991) Expression of FGF receptor gene in rat development. Development 111:455-468.

Weickert CS, Blum M (1995) Striatal TGF-alpha: postnatal developmental expression and evidence for a role in the proliferation of subependymal cells. Brain Res Dev Brain Res 86:203-216.

Weiss S, Dunne C, Hewson J, Wohl C, Wheatley M, Peterson AC, Reynolds BA (1996) Multipotent CNS stem-like cells are present in the adult mammalian spinal cord and ventricular neuraxis. J Neurosci 16:7599-7609.

Wichterle H, Garcìa-verdugo JM, Alvarez-Buylla A (1997) Direct evidence for homotopic, glia-independent neuronal migration. Neuron 18:779-791. 